\title{
Traditional Brands vs. On-Line Brands: A Comparative Assessment
}

Elizabeth Aderton, (E-mail: ela0645@mwsc.edu), Missouri Western State College Shiva Nandan, (E-mail: nandansh@mwsc.edu), Missouri Western State College

\begin{abstract}
In this paper we compare and contrast the branding strategies of traditional and on-line companies. To illustrate the similarities and differences between the two, we examine four wellestablished traditional brands and four successful on-line brands. We then offer recommendations for successful branding in the ever-evolving business and technological environment of the future.
\end{abstract}

\section{Introduction}

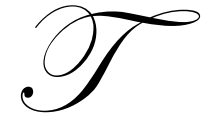

he advantages of building strong brands have been extensively documented in marketing literature (Farquhar 1989; Aaker 1991, 1996; Rust, Zethaml and Lemon 2000; Seetharaman, Nadzir and

Gunalan 2001; Deagon 2002). Successful companies have used branding as a strategic weapon to dominate their competition and develop a loyal customer base. Over the last decade the emergence of internet and its subsequent evolution from a distribution channel to a powerful marketing tool has created new opportunities for marketing managers. Specifically, the internet has given rise to a new breed of companies that owe their existence to this new electronic medium. Amazon, eBay, Ameritrade and TheStreet.com are examples of highly successful companies that conduct their business solely on the web.

In this paper we compare and contrast the branding strategies of traditional and online companies. To illustrate the similarities and differences between the two, we examine four well-established traditional brands Starbucks, Disney, Nike, and Mercedes-Benz. We then explore four web-based companies - Yahoo!, Drugstore.com, eBay, and easyJet. Finally, we offer recommendations for successful branding in the ever-evolving business and technological environment of the future.

\section{Key Concepts}

Before analyzing the branding strategies of successful companies it is important to clarify several key concepts, such as brands, brand equity, traditional brands and on-line brands.

Brands

According to Aaker (1991), "A brand is a distinguishing name and/or symbol (such as a logo, trademark, or package design) intended to identify the goods or services of either one seller or a group of sellers, and to differentiate these goods from those of competitors" (pg. 7). Gossen and Gresham (2001) define branding as the process of "identifying or creating, and then exploiting, sustainable competitive advantage" (pg. 1). Through branding, companies seek to gain this competitive advantage for their products, ideas, services, or the entire corporation.

Brand Equity

The tremendous value attached to a brand is often stated in terms of brand equity. "Brand equity is defined as the added value with which a brand endows a product" (Page and Lepkowska-White 2002, pg. 232). Strong 
brand equity can lead to loyal consumers who are familiar with the brand and have some favorable, strong, and unique brand associations (Keller 1993). Positive attributes associated with a brand can have a strong impact on brand equity. For example Disney, Intel and Coke benefit from positive consumer attitudes that become linked to a brand.

\section{Traditional Brands}

For the purposes of this paper, traditional brands are defined as brands that were established prior to the advent of internet and have been developed by companies who have traditionally conducted a large portion of their business through non-electronic channels. These companies are also called "brick and mortar" companies. For example, when one thinks of a coffee shop, a family entertainment brand, a luxury car, and an athletic brand, names such as Starbucks, Disney, Mercedes-Benz, and Nike come to mind.

\section{On-Line Brands}

These brands are a product of the internet. In other words, they rely almost exclusively on electronic media to conduct their business transactions. Page and Lepkowska-White (2002) have introduced the concept of Web equity, which is defined "in terms of Web awareness and Web image" (p. 232). The internet offers unique ways of communicating a company's message to the consumer. This is because of the increased interactivity that is made possible by the Internet (Duncan \& Moriarty, 1998).

\section{Traditional Brands}

Starbucks: Globalized Retailer

Coffee Everywhere

The first Starbucks opened in 1971 in Seattle, Washington (www.starbucks.com). Starbucks is a coffee retailer. The company began its business operations by opening a chain of retail stores. Starbucks has now expanded its product line to include many types of coffee and pastries to complement the coffee sold in these retail stores. It has also created coffee flavored ice cream and cold coffee called "Frappacino," which are sold in grocery and convenience stores (www.starbucks.com). Through these and other endeavors, Starbucks has become a wellestablished brand.

\section{A Realistic Mission}

The company's mission statement is to "Establish Starbucks as the premier purveyor of the finest coffee in the world while maintaining our uncompromising principles while we grow" (www.starbucks.com). Growing is exactly what the Starbucks Company has done. The 30-year old company is now serving up coffee worldwide with over 1500 stores in 28 countries and plans to open 13,500 more internationally. The company currently serves nearly 25 million customers per week (www.biz.yahoo.com).

"There is a Starbucks just about everywhere you go: every mall, every airport, every block in the big city--maybe even twice or three times a block" (Lund, 2000). Starbucks has even expanded beyond its own stores through joint ventures with Pepsi and Dryer's Grand Ice Cream to create their "Frappaccino" and the coffee flavored ice cream respectively (Lund, 2000).

\section{An Established Brand}

The Starbucks Company has established its brand with assurance of high-quality coffee products, as well as providing customers with the "Starbucks experience". This experience is one that can only be found with a Starbucks product and more often when purchasing the product in a Starbucks retail store. "You know what you'll get at a Starbucks ... Starbucks has built a brand that conveys not just a product but an experience" (Lund, 2000). 
Success through Expansions

The company has retail stores in almost every market in North America and is continuously expanding into the rest of the world. They have also created brand expansion by joint ventures with Pepsi and Dryer's Grand Ice Cream. When Starbucks committed to these expansions, they made a wise choice by choosing products that could easily be related to coffee and the coffee flavor. In addition, every Starbucks store strives to meet consumer expectations. This brand consistency has also led to their widening success.

Disney: Making Families Happy

Creation of a New Industry

The brand definition for Disney is "To make people happy" (Orzechowski, 2003). Disney began "making people happy" with small, animated films which have now evolved into an entertainment empire (www.providence.edu). Disney is the strongest family entertainment brand in existence, which is exactly what the brand's creator had hoped for. "Disney pursued a strategy that mirrored Walt Disney's philosophy of providing timeless and wholesome entertainment for the entire family" (Rajaram, 2003, pg. 1). The company's creator not only wanted entertainment for the entire family, but was the first to identify this market and put his ideas into practice.

Involved in Every Aspect of Family Entertainment

Over the last few decades, Disney has been expanding in all areas of the entertainment industry while trying to achieve the following corporate objectives: “. . (1) to build the greatest entertainment asset base in the world and (2) to simultaneously create the greatest entertainment product in the world" (Disney Annual Report, 1999). Disney has created movies, theme parks, hotels and resorts, cruise lines, a television station, and a variety of consumer products. Walt's widely recognized and loved characters have increased the degree of success along with his purchase of prime real estate in Florida and California. The most symbolically significant of their assets acquisition was the purchase of Disneyland, which was later followed by their second major theme park, Disney World (Disney Annual Report, 2002). Walt Disney's obsession with innovation has led to these and many other developments across the family entertainment business (Rajaram, 2003).

Maintaining a Strong Brand

Disney has a formidable reputation and is considered to be one of the strongest brand names in the world. Over the years it has generally succeeded in making the right tactical and strategic decisions. Disney knows how to best utilize its resources and capabilities in its market (Rajaram, 2003).

A good example that illustrates the idea that Disney's knack for allocating its resources wisely is their reluctance in opening a line of banks. Given the image of Disney as a fun entertainment company, when considering new endeavors, Disney compares this image to see how it would fit in this new environment. The idea of Disney opening a chain of banks may seem like an interesting venture, but then when compared with the Disney brand, one quickly realizes that this is not the correct industry for the Disney Company. People take banks seriously because people take their money seriously. Disney is about fun and fantasy and when comparing their brand to this serious business, the company knows that it should not invest its resources here (Orzechowski, 2003).

\section{Innovation and Brand Image}

Disney has found its success through a variety of it practices. Walt Disney's so-named "obsession" with innovation led to Disney's success through entering, and thus creating, the family entertainment business in the first place. The company has demonstrated a unique ability of determining what industries are right for the brand. According to Rajaram (2003) "this has enabled the company to maintain its strong culture and identity - after all these years, Disney is still 'Disney' and not a conglomerate of many loosely integrated entities” (page 1). 
Nike: The Goddess of Victory

Phil Knight, The Enterprising CEO

Nike began in 1968 in the trunk of CEO, Phil Knight's car. He and his track coach, Bill Bowerman, created the idea together. Bowerman had long been searching for a lighter, more durable running shoe for his team. Knight began to research this idea and started importing shoes to sell from Japan under Nike's original name, Blue Ribbon Sports. By the late 70s, Blue Ribbon Sport's name was officially changed to Nike, after the Greek goddess of victory (emediaplan.com, 2002).

A Winning Image

Choosing the right brand name, Nike, would become the first major step toward success for the company. As Nike was the name of the goddess of victory, consumers could associate Nike athletic apparel with winning. Therefore, Nike would be viewed as a winning brand (Ade, 2002).

The Nike logo came next. The unforgettable Swoosh was created by Carolyn Davidson, a graphic design student at Portland State University who Phil Knight later compensated with a large amount of shares of Nike stock (www.nike.com). The Nike swoosh is a "visual device that can't be mistaken for any body else's" (Ade, 2002). Over the years it has generated invaluable brand recognition.

Emotional Advertising

It was Nike's ability to appeal to consumers' emotions that really triggered consumers to see Nike as the athletic apparel to wear if one wanted to be victorious. Nike has kept this concept of winning in its advertising endeavors throughout its history. In many of its advertising campaigns Nike uses star athletes, like Michael Jordan and Andre Agassi, to promote its image. According to Liz Dolan, Nike's vice president of marketing, the company has always strived to have the best people in any sports communicate directly to consumers who would be buying shoes and apparel. This strategy of utilizing high-profile, successful athletes to build a winning brand that consumers could identify with has made Nike one of the most recognizable brands in sports. Consumers, especially kids, relate to these "winners" as someone they strive to be like (Rasmusson, 1998).

\section{Distribution Channels}

During its rise to the top, Nike distributed its shoes and athletic apparel in department stores throughout the world. Nike also created its own chain of stores that sold strictly Nike products called NikeTown. These distribution channels contacted seemingly all of the potential consumers in the world with Nike making billions a year (www.nike.com).

\section{Achievement: Athletic and Corporate Giant}

Phil Knight took Bill Bowerman's quest for perfection and his own business drive and created a powerful athletic company. The first step in Knight's success was striving to provide something that people, i.e. athletes, wanted and needed. Creating a name like Nike for the product only simplified his path to success. The remarkable logo of the Swoosh pushed success forward. The decision to use star athletes when promoting their product was a brilliant strategic move by the company. This really appealed to consumers and created an emotional bond between the brand and the target market. In addition, the company offered various distribution channels for their products worldwide making it easy for consumers to have access to its wide range of offerings. 
Mercedes-Benz: In the Business of Luxury

Luxury Cars for Over a Century

The Daimler-Motoren-Gesellschaft Company created the first Mercedes on December 22, 1900. The car was made for Emil Jellinek and was named after his ten-year-old daughter, Mercedes (www.vintage-carworld.com). Sixty-five years later Mercedes-Benz USA (MBUSA) was founded. MBUSA is headquartered in Montvale, New Jersey (www.mbusa.com). Over a century since the first Mercedes was created, MBUSA is now a participant in supporting one of the most innovative automobile brands in the world.

Innovation

Having sold over 19 million cars, Mercedes-Benz is committed to providing its customers with modern convenience and safety. Mercedes-Benz and the DaimlerChrysler Company developed safety technologies like ABS (anti-lock brake system) and airbags. The company has consistently made an effort to enhance the aspects of the comfort, safety, technology, and design of all models. (www.vintage-car-world.com).

Advertising to a New Audience

In the '90s, Mercedes-Benz decided to cater to a new market segment. Mercedes-Benz had long been viewed as a status vehicle that only older, successful men drove. The company had the goal of reaching a new group. Mercedes-Benz wanted to introduce a car that could be available to successful, young professionals. The company decided to adapt more emotions in their advertising campaigns for this new line. They adopted terms like "Inspiration," "Imagine," and "Dream." They made it easier for the potential consumer to read and relate to their catalogs. "We want to make Mercedes-Benz seem like the cars that people are wearing shorts to go to the 7-Eleven in, but we didn't want to cheapen the brand," explained Tim Meraz, the creative director for Mercedes-Benz (www.cdf.org).

Innovation in Advertising

Mercedes-Benz took a new approach to advertising and designing their vehicles in the USA. The company collected pertinent information on owners of off-road vehicles and current Mercedes car owners. They requested them to complete a questionnaire. The questions requested guidance from these people in creating a new MercedesBenz SUV. Questions included inquiries about engine size, exterior and interior colors, as well as to whether the spare tire should be on the inside or outside of the vehicle. Once the customers answered these questions, many of them started placing advanced orders. The customers felt like Mercedes-Benz was customizing a car just for successful people like them. This new approach will mostly like be used by Mercedes-Benz again as well as other car companies (www.brandingasia.com, 2001).

Mastering Luxury

Mercedes-Benz has held a firm grip on the luxury car business for years because it is dedicated to innovation, as well as the safety and comfort of its customers. By continuously creating new features and being concerned with what consumers want, the company has made its brand one of the most recognizable in the luxury car segment. Thus, through product innovations, improvements in the design and safety aspects of most models, and advertising through direct contact with the customer the company has succeeded in providing personalized service to the customer.

\section{On-line Brands}

On-line companies, or dot.coms, are Internet companies. They exist solely on the Internet. The web serves as their distribution channel, customer service channel, and method of providing information about the company and 
its products or services. These companies have been in existence for a relatively short period of time. Four such companies are discussed below.

Yahoo!: Turning a Hobby into BIG Business

David Filo and Jerry Yang: Creating Yahoo!

Yahoo! is an Internet based company. It is a portal to the Internet. "Yahoo! is the world's most visited Internet destination" (www.akamarketing.com). This Internet giant began in1994 in the minds and computers of two Stanford doctoral students, David Filo and Jerry Yang (www.yahoo.com). The two created this gateway to the Internet to help themselves organize web sites and resources they were interested in. Soon they realized they were not alone in desiring an easier way to navigate the Internet. Other students at Stanford began using the site and the reports about the web site spread by word-of-mouth leading to more hits everyday. Eventually Filo and Yang realized they had created a strong business opportunity (www.akamarketing.com).

Filo and Yang approached many Silicon Valley venture capitalists and eventually received nearly $\$ 2$ million in funding from Sequoia Capital. With additional funding in late 1995 from Reuters Ltd. and Softbank, Yahoo! was well on its way to becoming the Internet Goliath that it is today (www.yahoo.com).

First Internet Navigation System

Yahoo! is the first web navigation system of its kind, and as a consequence, gained the "first-mover advantage". It provides a search engine that allows users to access information from the entire web. Yahoo! also provides many free services such as email, travel, and yellow pages. Instead of charging for these services, Yahoo! earns a great deal of revenue through advertising (www.yahoo.com).

Advertising for Yahoo! and Advertising on Yahoo!

While Yahoo! itself advertises mostly through television, Yahoo! helps traditional marketers adapt their message to a web-based advertisement. Yahoo! provides industry experts to guide traditional marketers in creating a more web friendly design for their advertising messages. For example, Gap, Inc., has invested in advertising with Yahoo! "Our campaign designs for . . .Gap, Inc. have moved from simple point-of-purchases ads to coordinated efforts that integrate with other media efforts to promote mass awareness, build brand, and move product" (Annual Report, 2002).

Personalization and Globalization

The "MyYahoo!" feature has been a major factor in the popularity of the web-site. Every Yahoo! user can create their own Yahoo! homepage. It has items that are important to that particular user, for example, Yahoo! Finance, Travel, Shopping, News, Sports, etc. Thus by allowing users the ability to personalize, the company has succeeded in enhancing its brand equity.

Yahoo!'s website is appealing to users worldwide. Yahoo! is offered in a variety of languages in a many different countries. Innovations like these have lead Yahoo! to become one of the key players on the Internet.

Portal to Success

Yahoo! owes its success to the innovative thinking of two Stanford electrical engineering students' desires to create an easier navigation tool for their Internet use. In order to be successful the company had to create an image that it was consumers' gateway to the wide and mysterious world of the web, i.e., portal to the internet. Yahoo has convinced its users that it is the ultimate on-line navigational guide where surfers can get comprehensive information on a variety of topics including finance, weather, travel and entertainment. 
Drugstore.com: The Name Says it All

Providing What their Mission Suggests

Drugstore.com is exactly what its name suggests - it is an on-line drugstore. Not only is it an on-line drugstore, but it "is the leading online drugstore and information site" (www.drugstore.com). The company attempts to offer a convenient, confidential, and educational online shopping encounter to its customers. It opened in February of 1999 with the mission: "to serve the health, beauty, and wellness consumer with selection, convenience, information, personal service, and a trustworthy and reliable pharmacy" (www.drugstore.com).

Drugstore.com has set out to fulfill this mission by providing customers with personal reorder reminders, shopping lists, and order history access. The company offers 3-4 times as many health, beauty, and wellness products as traditional brick and mortar drugstores. The website also includes a special "Ask Your Pharmacist" feature. This feature allows customers to ask questions about both prescription and over the counter medications and get answers directly from drugstore.com pharmacists (www.drugstore.com).

Advertising Strategy

Drugstore.com advertises its site mostly through television commercials. The ads compare the online site directly with the traditional bricks and mortar drugstores in order to establish itself as the better drugstore (Appelbaum, 2001). Drugstore.com offers everything that is provided by other online drugstores. However, it has been able to gain competitive advantage by comparing itself to traditional drugstores instead of similar websites competing against it (Appelbaum, 2001).

The first television commercial of the company's first advertising campaign begins with a woman relaxing in her bathtub with a towel covering her eyes. People sneak into the woman's house and begin restocking all of her typical drugstore supplies. The commercial ends with the line 'You have better things to do then to go to the drugstore. Let the drugstore come to you' (Appelbaum, 2001). Thus, the convenience of ordering online rather then taking the 'time and effort' to physically go to the drugstore is being stressed.

\section{Successful Marketing Campaign}

The name drugstore.com is the first contributor to the company's success because it identifies exactly what the company is and is easy for consumers to remember. Drugstore.com provides customers with a personalized, private, informative, and convenient shopping experience, which contributes to the site's success. However, much of the company's success came through its marketing campaign. By positioning itself against brick and mortar competitors and not other online competitors, the company led customers to see drugstore.com as the "only" alternative to shopping in a traditional store. The ad campaign was instrumental in increasing their new customer orders three-fold. Creating a well thought out campaign led to a large expansion of their loyal customer base.

eBay: Only Online

eBay's Birth

When Pierre Omidyar found eBay in his San Jose living room in September 1995, the world of auctions and shopping was altered for good (www.cs.brandeis.edu). eBay is an online auction forum that has become the most popular shopping destination on the Internet (eBay, 2003). Omidyar's goal was to create "a marketplace for the sale of goods and services for individuals" (www.cs.brandeis.edu). This goal has evolved into the company's current mission: ". . . to provide a global trading platform where practically anyone can trade practically anything" (eBay, 2003). 
Worldwide marketplace

eBay allows buyers and sellers to come together in one place. Here buyers can purchase almost anything from one of eBay's 27,000 categories and 27 countries. eBay personalizes this shopping experience as well. Each buyer is able to personalize the items they hope to purchase, and the buyer is able to learn more about the seller. The seller sets up a personal profile, which includes feedback from previous buyers' experiences. Buyers may also email the seller directly if they would like to obtain more information about the product they are interested in (eBay Annual Report, 2002).

Not only has eBay created the marketplace that Omidyar had set out to create nearly a decade ago, but "... today the eBay community includes tens of millions of registered members from around the world" (www.ebay.com). And with more than 16 million items listed on any day, "people spend more time on eBay than any other online line site, making it the most popular shopping destination on the Internet" (www.ebay.com).

Online Entity without a Land Bound Counterpart

According to eBay CEO, Meg Whitman, much of eBay's success is attributed to the fact that there is no land bound company like it. There is no one place where a buyer can have access to so many products and sellers except online (Hof 2001). eBay has also continued to be successful because it offers customers security. They utilize the service of Billpoint.com to offer credit card protection against fraud. This has helped the company eliminate the risk to and perceived by their customers (King, 1999).

\section{Auction Success}

By creating the first and largest online auction web site, eBay has been able to gain first-mover advantage over the competition. To-date no other auction site, traditional or on-line, has been able to match eBay's unique capabilitie. By allowing direct buyer to seller interaction and costumer profiles eBay is in the enviable position of having the ability to directly meet consumers' personalized needs. eBay operates in over 27 countries and is rapidly acquiring a global brand status.

easyJet: Business Flies Online

Turning to the Internet

easyJet is another successful online company found by Stelios Haji-Ioannou. Formed in November 1995, easyJet initially offered two routes - from Luton to Glasgow and Edinburgh. It now offers over 106 routes in 38 European countries (www.easyjet.com, 2003). This company more clearly describes itself through its name than eBay or Yahoo!. easyJet is Europe's leading low-cost airline, and offers ease by booking air travel online (www.easyjet.com, 2003).

\section{Low Costs for the Company and for Customers}

easyJet uses the Internet for its bookings in order to keep its ticket distribution costs down. Approximately $90 \%$ of all of easyJet's seats are booked online (The remainder are booked through a call center). Customers booking their travel online get ticketless confirmation. They receive a detailed agenda of their travel plans and a confirmation number, thus creating even lower costs for the company and ultimately its passengers (www.easyjet.com, 2003).

easyJet uses many additional tactics to maintain its low costs. The airline does not offer free dining on their flights. The company does not serve meals on their flights, because so many passengers on airlines have complained about airline food. When passengers do desire meals, food is available on the flights for passengers to purchase (www.easyjet.com, 2003). Additionally, easyJet uses airports efficiently. "easyJet flies to main 
destination airports throughout Europe, but gains efficiencies through rapid turnaround times........" (www.easyjet.com, 2003).

Affordable Advertising

The company's advertising campaigns are economical, i.e., exorbitantly large sums are not allocated to advertising. This is consistent with the company's tradition of low-cost operations. Instead of trying to focus on new travelers, easyJet concentrates on consumers who have already decided to travel and "travel opportunists" who would travel when presented the right price (Appelbaum, 2001). The company's campaign mostly runs online through banner ads and has been very successful.

\section{Low Cost: Key to Success}

easyJet has made a successful airline out of a once two plane company. They have used the Internet to maximize their profits. By providing low-cost airfare to people who would have traveled anyway, the company built up its own sales while catering to the needs of its target market. The low-cost operations and advertising campaigns have enabled both, the company and consumers, to save money. This coupled with high-quality service and an "easy" name to remember has made easyJet a well-respected brand name for air travel.

\section{Comparative Assessment of Traditional and On-Line Brands}

\section{Simmilarities}

Innovation

A major similarity for successful traditional and online companies is innovation. Companies that come up with a new idea or product or even an appropriate extension are increasingly profitable. Walt Disney's innovation in the area of family entertainment created an entire new industry just as Yahoo!'s portal to the Internet was a new concept. Mercedes-Benz provides another good example of innovation in the way in which it has created new models to cater to the needs of its new and expanding consumer segments.

\section{Globalization}

Both traditional and online companies are finding it necessary to be able to market and adapt their products globally. The online companies were placed in a global market since their conception. Access to the Internet is available throughout most of the world, therefore access to online companies is just as widely available. Traditional companies are also becoming more and more globalized. Nike is available worldwide, people everywhere know who Mickey Mouse is, Starbucks stores are popping up daily in more and more countries, and Mercedes-Benz began its globalization decades ago.

\section{Designating the "Right" Name}

Brick and mortar companies as well as dot.coms can attribute their success to choosing the proper name. Nike chose the winning image by naming itself after the Greek goddess of victory. Drugstore.com and easyJet chose the "perfect" name somewhat differently. They named their companies such that their business/product was identified through the name. In other words, the brand names were also descriptors of the companies' businesses. As is obvious, either approach can add to success when the name relates to the product in consumers minds.

Personalization

While most often personalization is associated with online companies, traditional companies have also used it successfully. Mercedes-Benz created a strong feeling of personalization for its customers by requesting their input when creating new vehicles. Starbucks is able to meet customers' personal desires by offering a wide range of 
products in the coffee family. Internet companies create personalization through building tailored websites for visitors when they $\log$ in. Drugstore.com offers personalization through prescription reminders, past purchase access, and more. eBay allows customers to create profiles, bids for customers on certain products, and allows direct contact between buyers and sellers.

\section{Differences}

Distribution

Most traditional companies are able to offer more different distribution channels than online companies. When someone purchases an item from an online company, they usually must go to the company's website, purchase the item, and wait for delivery. Traditional companies often offer a variety of distribution channels, including the Internet. Disney is available in video stores, movie theaters, their own Disney stores, amusement parks, online, etc. Starbucks is available in its retail locations, as well as in grocery stores through its product expansions, and on-line.

\section{Differences in Cusomization}

Online companies can personalize the experience of each user. The entire homepage for each user on a website can be customized to fit that user's interests and desires. It is hard for a land-based, traditional company to match this ability to personalize an experience. While Starbucks can offer a variety of products to their customers, they cannot make each customers visit to their store a completely different experience. When a customer enters a Starbucks or NikeTown retail location, they know what to expect. Their locations are all very similar and standardized.

\section{Product Availability}

Online companies can easily offer more selection in their products. eBay, for example, has over 27,000 product categories. This is basically impossible for any traditional company to match. Yahoo! is able to offer a variety of services and access to information that no traditional company could match. It would be impossible to have that access without the use of the Internet and the use of a portal like Yahoo!

\section{Customer Service}

While online companies can offer customer service through e-mail and online chat, they cannot offer the direct person-to-person contact that a traditional company can. When customers are dealing with traditional companies, they know where to go when it comes to purchasing, maintaining, or discussing a particular product or service.

\section{Brand Building Recommendations}

A great deal can be learned from the successful traditional and online businesses discussed in this article. From their expertise and that of others, a list of key activities necessary to create a strong brand are outlined below.

\section{Choose an Approproate Brand Name}

Choosing a brand name should involve a great deal of thought and planning. Management has to decide whether the name of the brand should directly reflect the business that the company is in, e.g., drugstore.com, whether it should present consumers with an image of the brand like Nike, or whether it should be a name that will allow the brand to grow and eventually encompass many different business undertakings like Yahoo!.

It is also important to make sure that this brand name reflects a positive brand image. If the brand is going to be a global brand (as most successful brands now need to be), then it is important to choose a name that will have positive connotations in multiple cultures. 


\section{Create a Masterbrand}

A masterbrand is "the central force in progressive organizations that rallies all constituencies" (Upshaw, 2001, p36). This masterbrand should support the mission, vision, and beliefs of a company, and the brand should be thoroughly integrated throughout the company. The marketing team should not be the only group who understand what the brand's goals and image are, but it should be accepted through-out the company - from the production manager to the accounts payable department to the entry-level staff. Thus, all employees should have a clear understanding of the common goal and company mission.

The masterbrand is also very useful when it comes to advertising. It is important that this masterbrand has been determined prior to creating any marketing campaigns. Once this masterbrand has been designated, companies should carry this same brand image throughout all future ad campaigns. This will prevent consumer confusion as to what the brand is and how consumers should view it.

\section{Use the Internet to the Brand's Advantage}

The Internet can help a brand gain an advantage in many ways if used properly. A brand's website provides a message to consumers about that brand. A website should be easily navigated, reliable, personalized, and fast (Page, 2002). Consumers will not return to a website if it is not easy to use and access. If a website is not reliable, then consumers may also form this opinion about a brand.

When a company chooses to create a website advertising their product, it is important that the information on the website is relevant as well. Companies should provide information that is accurate and applicable to consumers' needs. This is one of the best and easiest ways for a consumer to gather knowledge about a product or service.

Once the website has formed, and a positive brand image is portrayed through this website, consumers will be willing to purchase items directly from the website. Companies with strong brands should take advantage of this opportunity and offer online shopping. Offering products through the Internet creates a quick and easy way for consumers to shop while benefiting the company through savings in on distribution costs and showroom space. Using the internet in combination with other distribution channels allows the company to reach the widest market currently available.

\section{Personalization and Customization}

The practice of personalizing or customizing brands is becoming more and more important to customers. "Customized products and communications attract customer attention and foster customer loyalty and lock-in" (Ansari, 2003, p131). The Internet creates an easy method of offering customization to customers. Websites can be specifically designed to recognize returning users and offer product suggestions to that user; thus, creating more of a personalized experience for the consumer and making them eager to return.

Other companies can offer personalization in different ways. Traditional companies can listen to their customers to find what is important to them. When Mercedes-Benz did this with their new model of SUVs, the company saw an increase in presales. Before the product was even complete, customers were placing orders for the models. This was in large measure a result of consumer perceptions that Mercedes-Benz was appealing to them personally.

\section{Customer Service}

Personalization is also closely related to customer service. Prompt, courteous and effective customer service helps promote customer satisfaction. When consumers perceive that they are important to a company's success, they are more likely to become repeat purchasers of a brand. 
eBay works to ensure customer satisfaction by allowing direct contact between buyer and seller. Both buyers and sellers are able to rate each other on performance and quality, thus providing a service for future users. Customer service is important for both online and offline companies. Online companies often offer customer service via e-mail and chat, but this is not always enough. Research has found that when making transactions online, 91 percent of consumers desire human contact at some point during the transaction (Lewis, 2000). Therefore it may become increasingly vital that online companies create a "call-in customer service center".

Another issue that can easily be grouped in the customer service category is customer privacy. It is important to keep all personal information about a customer that a company obtains private. If this information is shared with others companies for marketing purposes, customers may lose trust and, as a consequence, may discontinue doing business with the company.

The personal or financial information of consumers and users on websites can also sometimes be accessed by computer hackers. This is a major concern of many online shoppers. It is important that companies employ an adequate security system and create confidence among its patrons.

\section{Advertising}

It is important to create a consistent image for a brand. When consumers view the message of the advertisement, they should be able to easily connect the message to the brand's image. In order to reach these consumers, advertising should be done through many different media in order to target the largest number of potential consumers. Before beginning any advertising endeavor, the appropriate market segment should be determined.

\section{Social Responsibility}

A simple way to reach customers and help a brand gain respect is to be socially responsible. Most companies participate or sponsor various charities and community services. Customers can really relate to an organization that is helping others like them. If a company or brand is involved in such activities, it is important to publicize these events. Consumers who relate to and support the company's activities will be more likely to purchase that brand instead of an alternative.

\section{Conclusion}

In today's highly competitive business climate companies with strong brands can generate huge profits by catering to a loyal and expanding consumer base. In this paper we have demonstrated how successful brands operate, both traditionally and on-line. Marketing managers can utilize some of the brand-building techniques used by companies discussed above. Future technological advances will most likely blur the distinction between traditional and on-line brands. In order to be successful, companies will have to create brands that transcend such differences and can cater to changing consumer needs in a global context.

\section{References}

1. Aaker, David A. (1991), Managing Brand Equity: Capitalizing On The Value of a Brand Name. New York: The Free Press.

2. $\quad$ Aaker, David A. (1996), Building Strong Brands. Free Press. New York, NY.

3. Ade, G. N. (2002). Branding in Six Lessons. Brandtutorial.com; www.brandtutorial.com/brandfood/.

4. Ansari, A., and Mela, C. F. (2003). E-Customization. Journal of Marketing Research, 131.

5. Appelbaum, U. (2001). Best Practice: The Principles of Effective Advertising for Dotcoms; www.first thetrousers.de.

6. Deagon, Brian (2002), "Brand-Building Means More Than Just Advertising A Product," Investor's Business Daily, April 5, p. A3.

7. Drugstore.com: Corporate Profile (2003); http://www.shareholder.com/drugstore/profile.cfm. 
8. Duncan, T., and Moriarty, S. E. (1998), "A Communication-based Marketing Model for Managing Customer Relationships", Journal of Marketing, April, Vol. 62, 1-14.

9. Dyson, C. J. (2002). Starbucks decaffeinated; www.brandchannel.com/features_webwatch.asp?id=75.

10. easyJet.com (2003).

11. eBay.com (2003).

12. eBay Annual Report (2002).

13. Farquhar, Peter H. (1989), "Managing Brand Equity," Marketing Research, Vol. 1, September, 24-33.

14. Gossen, R., and Gresham, S. (2001). Branding as the Foundation of Sustainable Competitive Advantage. http://www.brandchannel.com/papers_review.asp?sp_id=146.

15. Hof, R. D., (2001). Online Extra: Q\&A with eBay's Meg Whitman. Business Week Online. http://www.businessweek.com/magazine/content/01_13/b3725036.htm.

16. Keller, Kevin L.(1993), "Conceptualizing, Measuring, and Managing Customer-Based Brand Equity," Journal of Marketing, Vol. 57, No. 1, 1-17.

17. King, J. (1999). Web Sites Crack Down on Fraud. Computerworld, Sept. 13, 1113.

18. Lewis, E. \& Morrison, D.S. (2000). Ten Ways to Build a Better Business. News Media Age, Mar. 30, 30-38.

19. Lund, B., (2000). Starbucks' Brand Power;__www.fool.com/portfolios/rulebreaker/2000/ rulebreaker001205.htm? source=EDTRB.

20. Mercedes-Benz USA: Our Company (2003);www.mbusa.com/brand/aboutus/company/company.jsp.

21. Nike.com (2003).

22. Orzechoweksi, K. (2003). Building an Operationalized Brand. www.accessdc.com/pdf/ WP_Branding.PDF.

23. Page, C., and Lepkowska-White, E. (2002). Web Equity: A Framework for Building Consumer Valuein Online Companies. Journal of Consumer Marketing, 19, 231-248.

24. Rajaram, A. (2003). Competitive strategy: Disney Case Write up. http://faculty.haas.berkeley.edu/ meghan/299/case_analysis_Disney3.pdf.

25. Rasmusson, E. and Ligos, M. (1998). Please Tell Me How. Sales and Marketing Management, 150, 137142.

26. Rust, R., V. Zeithaml, and K. Lemon (2000), "Driving Customer Equity”, Free Press: New York

27. Seetharaman, A., Z. A. Nadzir and S. Gunalan (2001), "A Conceptual Study On Brand Valuation”, Journal of Product \& Brand Management, Vol. 10, No. 4, 243-256.

28. Starbucks.com: the company (2003). http://www.starbucks.com/aboutus/overview.asp.

29. Upshaw, L., (2001). Building a brand.comm. Design Management Journal, 12, 34-39.

30. Walt Disney Company Annual Report (1999).

31. Walt Disney Company Annual Report (2002).

32. www.akamarketing.com (2003). The Story of Yahoo; www.akamarketing.com/yahoo-feature1.html.

33. www.brandingasia.com (2001). Cases archive: Mercedes-Benz USA-Design and Launch of the New ' $M$ ' Class Off-roader. www.brandingasia.com/cases/mercedescase.htm.

34. www.cdf.org (No Date). Mercedes-Benz: Driving Emotion. www.cdf.org/cdf/atissue/vol2_2/ mercedes/mercedes.html.

35. www.cs.brandeis.edu (2001). ebay's History: www.cs.brandeis.edu? magnus/ief248a/eBay/history.html.

36. www.emediaplan.com (2002). Nike-Brand Story; www.emediaplan.com/admunch/Brands/nike.asp.

37. www.providence.edu (No Date). Walt Disney Company Overview.

38. www.providence.edu/polisci/affigne/students/disney/overview.htm.

39. www.vintage-car-world (2000). Mercedes-Benz-The Story of Passion_www.vintagecarworld.com/ service/mb100.htm.

40. Yahoo! Annual Report (2002).

41. Yahoo.com (2003).

42. Yahoo! Finance (2003). Starbucks Steaming Toward Long-Term Profitability and Growth Internationally. 
$\underline{\text { Notes }}$ 